\title{
Literary interpretation of ceremonial folklore in the works of Togay Murod
}

\author{
Kambarova Saodat Irkinovna ${ }^{1}$ \\ ${ }^{1.2} \mathrm{PhD}$ of pedagogical sciences, teacher of Alisher Navai Tashkent state \\ university of the Uzbek language and literature \\ saodat7373@mail.ru
}

\begin{abstract}
The article discusses the examples of ceremonial folklore, effectively used in the story "Oydinda yurgan odamlar" ("People walking in the light") by Togay Murad, a prominent Uzbek writer. The role of these songs as a reflection of the nation's outlook, dreams and hopes. In the framework of the article, series of traditional songs for milking called "Turey-turey" that specially addressed as an artistic expression of the inner worlds of the heroes; lullabies, a shining example of children's folklore; mourning songs that are sung over the tracking of people on their last journey; the importance of legends, myths and riddles in the upbringing of the younger generation, which is the expression of the artistic thinking of the nation have been addressed. It also discusses the issue of developing students' research skills and competencies through the analysis of the meaning embedded in the essence of folklore in the process of literary education. Bull, riddle.

Key words. Folklore, "Turey-turey", lullabies, mourning songs, mourning, legend, narration, Sufi Allayar, Holy
\end{abstract}

\section{Introduction.}

Well-known Uzbek writer Togay Murad's works, rich in national values and folklore, are distinguished by their unique closeness to the common people. After all, his story "Oydinda yurgan odamlar" ("People walking in the light") is noteworthy for the effective use of ancient customs, examples of folk art in illuminating the inner world and outlook of the nation through the example of the character of the heroes and their lifestyles. In the play, the author describes the sincere feelings of two souls, "the life of the grandfather of a non-existing child and the grandmother of a non-existing child, spending their whole lives together year after year ... is described very delicately and poetical. He sings their mutual love like a song. Togay Murad describes two pure souls, who call each other as "Grandfather" and "Grandmother", living their lives wrapped in the moonlight" [Togay Murad, 2008: 7-8].

The heroes of the story are Qoplonbek and Oymomo. They are the epitome of brave people who have been expecting children for years and whose patience has been refined in the fires of life. The author interprets the fact that childlessness is the unhappiness of humanity in the example of the fates of the protagonists, Qoplonbek and Oymomo. The story is characterized by the personality of the writer, who has been in touch with rich spiritual heritage, grew up in harmony with national traditions and customs and unique examples of folklore.

\section{Main part.}

The description of sufferings of Oymomo because of her infertility in the folklore style, has become one of the factors that ensures the narrative's impact. Craving for a child she loses her mind. The grief of passing away from the world without having a child tortures and torments her heart endlessly. She wants to share this burden with someone, so as to ease the pain. The folk songs mentioned in the story are close to and in harmony with her spirit.

It can be inferred from the story that "Turey-turey" songs that are of the series of labour songs were used to illuminate the heartache of a woman who is losing her last hopes to ever hold her own child. The author uses the image of Oymoma's singing during the work so as to point out two factoids: first of all, it is that stockbreeding is an integral part of the life of the people of the Surkhandarya oasis; secondly, it can be interpreted in the form of illuminating the sufferings of infertility, which are deeply rooting the Oymoma's heart.

"Our mother started milking the cattle.

Sovdi bo'lib sovdirgin, turey-turey, Sovsa kadi to'ldirgin, turey-turey. Buncha kuyma, jonivor, turey-turey. Taqdiringni ko'ndirgin, turey-turey.

Sovliq iydi, sovliq qo'zisiga tumshuq cho'zdi...” [Togay Murad, 2008: 282].”

Translation: (Let me milk you hush, my dear; Let me full the dishes, hush my dear; don't you worry, hush, hush my dear; The cow calmed down, the cow made for its child).

There is a symbolic meaning in Oymomo's pouring out the pains that have plagued his heart for years on livestock, not humans. The words "don't worry" and "persuade your destiny" in the comforting tone of the passage will not leave the intelligent reader indifferent to the fact that she was not only trying to calm down the cow but also urging herself to accept her bitter fate.

A unique gem of children's folklore, a lullaby, touches the precise feeling of the reader and directs the hero's inner experiences. The song sung from the day a child is born is called "alla" or a lullaby. The tradition of lullaby singing has long 
been inherited by the Uzbek people. It has a positive effect on the child. Although the child may not be able to comprehend the content of the song dedicated to him while lying in the crib, the tone does have a positive effect on him. Hence, the lullaby is the expression of the feelings of affection between mother and child. In the lullaby performed to comfort and put babies to sleep, the mother's high hopes for the perfection of her child, her endless love, as well as her sorrows and aspirations, are sung to help describe Oymomo's sorrowful inner world. The lullabies on the daily themes, which are an expression of women's happiness or tragedy in their personal lives, provide an in-depth look at the spiritual world of the protagonists in the play.

Momo, who smelled the sweetness of the neighbour's baby, compared to the fragrances of heaven, involuntarily sings a sad and sad song:

"Alla-alla, ahdi bor-a, alla-yo, alla-yo, Uyquning ham vaqti bor-a, alla-yo, alla-yo, Alla aytgan enangni-yo, alla-yo, alla-yo, Qop-qoraygan baxti bor-a, alla-yo, alla-yo.” (Togay Murad, 2008: 337)

Translation: ("Alla-alla, there is a covenant, alla-yo, alla-yo, there is a time for sleep, alla-yo, alla-yo, the mother of your singing a lulliby, alla-yo, alla-yo, has a very bad luck, alla-yo, alla-yo.”)

These lines invoke in the imagination of the reader all the years full of moans of the protagonist in the face of discrimination, humiliation, reproach. Grief-stricken verses warn of the state of mind of a poor woman whose desire to have a child never dies, even when on her deathbed. The fact that the concept of "happiness" in the lullaby is expressed in black also serves a purpose. The hidden truths of the verses imply that motherhood is a unique grace of God Almighty bestowed on a woman, and that deprivation of this blessing is unfortunate.

Oymomo feels the joy of motherhood, though, in the last moments of her life, under the influence of the miraculous melodies of the song. Milk comes to the breast of a grandmother who caressed her neighbor's young child and died. In the play, the song is used not only as a means of expressing the feelings of the protagonist but also, in a sense, as a response to her dreams. Apparently, in the lullaby, "the mother tries to sing about the problems and pains that torment her" [Safarov. 2010: 337].

Although the issue of love and childlessness is firmly rooted in the story, we see that in the example of the heroes' way of life, the examples of ceremonial folklore have become an integral part of the nation's spirituality in harmony with Uzbek traditions and customs.

It is well known in folklore that the genres of ceremonial folklore are divided into such types as seasonal folklore and family ceremonial folklore. A ceremony is an event dedicated to the celebration of important events of human life, which takes place in a formal and spiritual atmosphere, with its own symbolic actions and special songs. The author also pays attention to family mourning ceremonies in the story. After all, life is not always about good days and joys.

Much of the mourning folklore consists of mourning songs, which have been performed since the day of the funeral till ceremonies (such as "three", "seven", "twenty", "forty", "hundred", "year") pass; the ritual is performed with tears in front of people who come to offer condolences to the family members of the deceased. These ceremonial mournings are mostly one-offs and are vary depending on the situation. In mourning, words such as "voy-voy-ey" and "voy-dod-ey" indicate the relation of the singer to the deceased. The meaning of the tears at the funeral of Momo, who passed away, is also unique. It is worth noting that, although Momo passed away without offspring, the sincere sadness and tears of the villagers who did not have any blood-kinship with her and their attempt to support her husband manifest the unity of the Uzbek nation in the struggle and human qualities of our mentality.

The young women wept bitterly for her:

Osmondagi qirq yulduz, Qiyalab ketadi botgani. Voy momom-ovv, momom-ovv!.. Men momoni bir o‘payin, Qiyomat ketadi yotgani. Voy momom-ovv, momom-ovv!.. (Togay Murad, 2008: 338).

Translation: (Forty stars in the sky, went to eternal sleep. Oh my granny, oh my granny! Let me kiss her farewell, never shall I her again. Oh my granny, oh my granny!)

Here the end of human life is likened to the death of stars in figurative images. The deceased is described by the mourner as "a mountain to lean on," "a garden to believe in," "a star in the sky," "a bright day in life," and so on. Consequently, "The main task of a mourning song is to remember all the qualities of the deceased and to react to the tragedy" [Madayev, 2010: 94].

It is known that in world mythology, the tree is recognized as a material shell that protects human life. In his research, ethnographer E. Taylor emphasizes two important aspects of the mythological notion of the tree. These are:

1) the idea that every plant, first and foremost a tree, is alive, gave rise to the tradition of worshiping trees;

2) Plants (including trees) can act as shells for the materialization of the soul after death.

Therefore, our ancestors "thought that trees were related to them, spiritually close to them, and that the human soul exists in the tree before birth and after death, which contributed to the formation of beliefs about the world of trees and plants" [Taylor, 2000: 186].

Elements of such attitudes remain at the heart of the Uzbek people's custom of mourning at funerals and the holding willow sticks for the funeral procession by the mourners. The essence of the planting of twigs around the tomb was the belief that when a person died, his soul would move to the tree through the cane. According to funeral rites a willow cane was an alternative to the tree, and that the soul passed through it to the tree after death. 
In Gadoeva's research, this habit "embodies beliefs about the eternity of the soul, that is, the continuation of the human soul as a tree" [Gadoeva, 2012: 39].

The reasons for visiting the tomb of Hazrat Sufi Allayar, the tradition of calling the day when Jamshid, a king of the Tahmuras dynasty, came to power as Navruz, then Kayumars became king and he celebrated Navruz, the ceremony of cooking sumalak legends and myths play a significant role in the play.

It is well known that legends, which are considered to be one of the epic types of folklore, tell stories that could occur but in reality, had never happened. The legends are founded according to the imaginary plots that have completely made up by people, whereas the myths are the stories that might actually happen in the real life. The story tells the myths and legends about the origin of activities and place names, assigned to the hopes and beliefs of a childless couple. Our heroes, who are burnt to ashes by the pain of infertility, visit the graves of saints, worship at holy shrines, approach fortune-tellers and healers. There is a scene of sacrificing of a lamb at the foot of the tomb of Sufi Allayar. Allayar was originally from Samarkand and lived in the XVII-XVIII centuries. He is the author of "Murad ul-Arifin", "Tuhfat ul-Talibin", "Maslak ulmuttan", "Sabot ul-ojizin", "The wish of Musannib (p.b.u.h.)". The deification and sanctification of the name Alloyar in the play is connected with the following narration:

"It simply came to Allayar's notice that there was no water in Vakhshimar.

Then Olloyor went along the river. He went to the bottom of the river. A place was wet, and the water was glistening. Allayar shoved the moisture with his stick. Water gushed from the ground.

He said to his student, "Head in the direction of Vakhshimar drawing with this stick on the ground.

"Then his student said, "If the water is low and Vakhshimar is high, how will the water come out?"

- He said."You go up in the footsteps of a snake, and the water will run out," said Allayar.

Indeed, the water rose in the footsteps of the stick and make off to Vakhshimar. The water flowed from below! Allayar glanced at the water and said to everybody:

"Look, it's a spring!". The spring was called Karabulak. For two centuries, Karabulak flowed from below. It did not dry out in winter and summer. It was warm in winter and cold in summer" [Togay Murad, 2008: 255].

The mausoleum of Sufi Allayar mentioned in the play is located in the village of Vakhshivar of Altynsay district of Surkhandarya region. The Karabulak hydronym belongs to this region. The fact that childless families go to the shrine of Sufi Allayar means that the people believe to semi-real, semi-fantasy events. This means that the writer has a creative approach to popular beliefs.

And in the legend of the Holy Bull, it is impossible not to understand the beliefs of the settled people who were engaged in farming. The image of the Bull (cow) in this legend also shows the effective use of Zoroastrianism, folklore and the scientific heritage of our ancestors.

It is known that Nosiruddin Burhaniddin Rabguzi, who lived at the beginning of the XVIII-XIV centuries, in his work "Qissas ar-Rabguzi" about prophets, said that the sky and the earth consist of seven layers, each of which has its own name and appearance.

For example, although the seven heavens are said to have been inhabited by certain prophets, the preface states that the heavens are under the control of angels in the form of different animals and that the angels are of different colours. The angel in charge of the third floor is described as a cow (bull) [Nosiruddin, 1990: 147].

The sacred book of Zoroastrianism, the Avesta, also contains interesting information about cows. In particular, "the fifth battle was fought by a single created cow. After his death, herbs were created from its members. The light and power in the semen of the cow was given to the moon" ["Avesto", 2001: 351].

According to researcher Z. Shukurova, "The text states that the cow has risen to the level of great power, which is the reason why the moon is a source of light. The view of the cow as a supreme being and a special reverence for it is mentioned in many places in the Avesto"[Shukurova, 2015: 136].

According to the folklorist T. Mahmudov, "Zoroastrians considered breeding of cows sacred". The scholar also analyzed Ahura Mazda's six great oaths and found that his fourth oath was called the "cow's oath" [Mahmudov, 2000: 19]. So the image of a cow (bull) is a divine being in the eyes of Ahura Mazda, whose incomparable power and light have been seen to be even more of the moon. The content of the following legend in the plot of the story is in line with the views of the Avesta:

“... The Holy Bull is made of the light of the sky ... The horns of the Holy Bull ... are made of gold ... the hooves ... are made of silver! .. The moon rises in the chariot of the Holy Bull! .. The man who sees the Holy Bull once will have all his dreams fulfilled!" (Togay Murad, 2008: 264).

The story also contains folklore riddles with a specific purpose, which serve to show the richness of the worldview, imagination and artistic thinking of the protagonists. The riddles that are told in the process of sumalak cooking help to embody the life of the people, as well as the nature of grandmothers and girls, such as poetry, wit, ingenuity, intelligence and taste.

The conversation was started by Kholdon momo. A wide variety of traditional riddles such as: "The meal of a small pot is sweet" (walnut), "Not a dog, so doesn't bark, not a man, doesn't allow to enter a house" (lock), "Brothers live, they do not see each other" (eye), "I saw a meal without salt" (sumalak) - made the story interesting, readable and attractive. 
Apparently, the riddles, used in conjunction with seasonal ceremonies, give the reader a warm impression of the intelligence of the women of the Surkhandarya oasis, the feeling of eloquence.

\section{CONCLUSION}

In conclusion, the reader will enjoy the rich spiritual heritage created by our ancestors through the study of folklore and ceremonial songs, described in the story "People walking in the light," and will develop their artistic and aesthetic thinking. Readers will be interested in conducting research on the enviable values of the Uzbek people, their unique traditions, independent research on customs and traditions, on the example of seasonal and family ceremonial folklore genres typical of the Surkhandarya oasis, where the author was brought up. It also allows students to explore the individual characteristics of the creative personality and to understand the depth and width of their worldview.

\section{References:}

* “Avesto". - Toshkent: Sharq, 2001. - P. 383.

\# Gadoeva D. Daraxt bilan bog'liq totemistik qarashlar // O‘zbek tili va adabiyoti. - Toshkent, 2012. № 2. - P. 39.

* Madayev O., Sobitova T. Xalq og'zaki poetik ijodi. - Toshkent: Sharq, 2010. - P. 208.

* Mahmudov T. “Avesto" haqida. - Toshkent: Sharq, 2000. - P. 63.

* Nosiruddin Burhonuddin Rabg'uziy. Qisasi Rabg'uziy. - Toshkent: Yozuvchi, 1990. - P. 240.

\# Safarov O. O‘zbek xalq og'zaki ijodi. - Toshkent: Musiqa, 2010. - P. 368.

\# Taylor E. Mif i obryad v pervobitnoy kulture. - Smolensk, 2000. - P. 186.

* Togay Murod. Tanlangan asarlar. I jild. - Toshkent: Sharq, 2008. - P. 448.

\$ Shukurova Z. Rabg'uziy va folklor. - Toshkent: Tamaddun, 2015. - P. 200. 